\title{
Perilaku Petani terhadap Program Gerbang Pangan Serasi (Kasus di Subak Tajen, Desa Tajen, Kecamatan Penebel, Kabupaten Tabanan)
}

\author{
AGUNG PUTRA INDRA GUNAWAN, I DEWA PUTU OKA SUARDI, \\ WAYAN SUDARTA \\ Program Studi Agribisnis Fakultas Pertanian Universitas Udayana \\ Jalan P.B. Sudirman Denpasar 80232 \\ Email: agungindra50@yahoo.com \\ okasuardi@unud.ac.id
}

\begin{abstract}
Farmer Behavior towards the Program of Gerbang Pangan Serasi (A Case at Irrigation Organization of Subak Tajen, Village of Tajen, Penebel Sub-District, Regency of Tabanan)
\end{abstract}

Continuous use of inorganic fertilizer for a long time has had a negative impact on soil and the environment. In order to maintain the existence of the agricultural sector and to implement the efforts towards organic agriculture, the local government of Tabanan Regency established a flagship program called the Gerbang Pangan Serasi (GPS) Program. This study aims to determine the behavior of farmers towards the Gerbang Pangan Serasi (GPS) Program, which is measured from the level of knowledge, attitude, and skills. The research was conducted in Subak Tajen, Tajen Village, Penebel Sub-District, Tabanan Regency. The selection of research site was done purposively. The population was the Subak Tajen members who received the Gerbang Pangan Serasi (GPS) Program as many as 34 people. With the census technique, 12 farmers who received the aid of cattle were taken as respondents, plus 12 farmers who did not receive the aid of cattle. Thus, the total number of respondents was 24 people. Based on the findings of the research, it is known that the behavior of farmers who received the aid of cattle towards the Gerbang Pangan Serasi Program is good category, with knowledge score of 3,91, attitude score of 4,08 and skill score of 4,82 . Whereas, the behavior of farmers who did not receive the aid of cattle was in moderate category, with the knowledge score of 3,01, attitude score of 3,69 and skill of 2,78. Thus, the behavior of farmers who received cattle assistance is categorized as good category with the score of 3.94 and the behavior of farmers who did not get the aid of cattle is classified as moderate category with the score 3.35. Based on the findings, it is suggested to farmers that they should be willing to apply technology and innovation in the field of agriculture provided by extension workers, because the farmers will get new experiences to be applied in their farming.

Keywords: farmer behavior, knowlage, attitude, skills, subak 


\section{Pendahuluan}

\subsection{Latar Belakang}

Indonesia merupakan negara agraris dan sebagian besar penduduknya bermata pencaharian di bidang pertanian, namun pada saat ini petani lebih banyak menggunakan pupuk anorganik dalam usahataninya karena nutrien dari bahan anorganik lebih mudah diserap tanah dan memiliki kandungan hara yang tinggi. Pemakaian pupuk anorganik dengan dosis yang tinggi secara terus-menerus dalam waktu yang lama telah memberikan dampak negatif terhadap tanah dan lingkungan (Lee at al. 2002 dalam Gustian Nugraha N, 2013). Penggunaan pupuk kimia sintetis atau pupuk anorganik yang tidak terkendali menjadi salah satu penyebab penurunan kualitas kesuburan biologis, fisik dan kimia tanah.Selain itu, residu pupuk kimia sintetis merupakan salah satu penyebab utama mengerasnya tanah-tanah pertanian (Adi, Istiqomah Buddhisatyani, 2013).

Menyambut upaya menuju pertanian organik, Pemda Kabupaten Tabanan membentuk program unggulan yang dinamakan Program Gerbang Pangan Serasi (GPS) yang dituangkan dalam Peraturan Bupati Nomor 51 tahun 2012. Pada tahun 2015 Pemerintah Daerah Kabupaten Tabanan kembali melaksanakan program unggulan sektor pertanian yaitu Program Gerbang Pangan Serasi di subak/subak abian yang telah terpilih, salah satunya adalah subak Tajen, Desa Tajen, Kecamatan Penebel, Kabupaten Tabanan (BP3K Kabupaten Tabanan, 2015).

Pengetahuan petani mempunyai arti penting dalam akselerasi pembangunan pertanian, karena pengetahuan petani dapat mempertinggi kemampuannya untuk mengadopsi teknologi baru di bidang pertanian. Jika pengetahuan petani tinggi dan petani bersikap positif terhadap suatu teknologi baru di bidang pertanian, maka penerapan teknologi tersebut akan menjadi lebih sempurna, yang pada akhirnya akan memberikan hasil secara lebih memuaskan baik secara kuantitas maupun kualitas (Sudarta, 2005). Melihat fenomena tersebut, maka peneliti tertarik untuk mengadakan penelitian mengenai perilaku petani terhadap Program Gerbang Pangan Serasi di Subak Tajen.

\subsection{Tujuan Penelitian}

Sejalan dengan permasalahan yang telah dirumuskan, maka tujuan dari penelitian ini untuk : (1) mengetahui tingkat pengetahuan petani tentang Program Gerbang Pangan Serasi; (2) mengetahui sikappetani terhadap Program Gerbang Pangan Serasi; (3) mengetahui keterampilan petani tentang Program Gerbang Pangan Serasi.

\section{Metode Penelitian}

\subsection{Lokasi dan Waktu Penelitian}

Penelitian dilaksanakan di Subak Tajen yang beralamat di Desa Tajen, Kecamatan Penebel, Kabupaten Tabanan (Anonim, 2014). Penelitian ini dilaksanakan pada bulan Oktober 2016 sampai dengan Desember 2016. Penentuan 
lokasi penelitian ditentukan secara purposive yaitu penentuan lokasi penelitian yang dilakukan secara sengaja (Singarimbun, M dan S. Effendi, 1989).

\subsection{Penentuan Populasi dan Responden}

Populasi adalah jumlah keseluruhan dari satuan-satuan atau individu-individu yang karakteristiknya hendak diteliti (Rowland B. F. Pasaribu, 2013). Populasi dari penelitian ini anggota Subak Tajen yang menerima Program Gerbang Pangan Serasi sebanyak 34 orang. Menggunakan teknik sensus, 12 orang petani yang mendapat bantuan sapi ditetapkan sebagai responden, sedangkan petani yang tidak mendapat bantuan sapi ditetapkan sebanyak 12 orang secara acak. Seluruh responden dalam penelitian ini berjumlah 24 orang.

\subsection{Teknik Pengumpulan Data, Instrumen Pengumpulan Data, dan Metode Analisis}

Teknik pengumpulan data yang digunakan yaitu observasi, wawancara, studi pustaka, dan dokumentasi. Instrumen penelitian yang digunakan adalah kuesioner dengan memberikan pertanyaan atau pernyataan tertulis untuk mendapatkan informasi dari responden (Gulo, 2002). Metode analisis yang digunakan adalah kuantitatif dan kualitatif.

\section{Hasil dan Pembahasan}

\subsection{Karakteristik Responden}

Karakteristik responden dalam penelitian ini meliputi umur, tingkat pendidikan formal, mata pencaharian, jumlah anggota rumah tangga, dan luas lahan garapan.

\subsubsection{Umur}

Umur merupakan salah satu faktor yang menentukan produktivitas kerja, dengan kisaran 15 sampai 64 tahun. Umur juga mempengaruhi pendapat seseorang terhadap rangsangan yang datang pada atau yang dirasakannya (Thoha, 2004). Hasil penelitian menunjukkan bahwa rata-rata umur responden adalah 54,75 tahun yang terdapat pada kisaran kelompok umur 40 tahun sampai 70 tahun, sebanyak 17 orang $(70,83 \%)$ termasuk dalam kategori produktif, sedangkan tujuh orang $(29,17 \%)$ termasuk dalam kategori non produktif.

\subsubsection{Tingkat pendidikan formal}

Distribusi responden berdasarkan tingkat pendidikan formal dibedakan atas tidak sekolah, tamat SD, tamat SMP, dan tamat SMA. Pendidikan merupakan salah satu faktor yang mendorong kemampuan seseorang untuk menyerap teknologi dan ilmu pengetahuan. Tingkat pendidikan yang memadai membuat petani akan semakin mengerti dan memahami materi-materi yang disampaikan atau diberikan oleh penyuluh serta mempengaruhi kemampuan petani untuk menerima dan mencoba inovasi baru (Thoha, 2004). 
Dikemukakan oleh Mosher (1991), bahwa pendidikan membuat seseorang berpikir secara rasional terhadap apa yang dilakukan, membuat seseorang lebih mampu mengambil keputusan atas berbagai alternatif dalam mengelola usahataninya. Berdasarkan hasil penelitian, dapat dijelaskan bahwa tingkat pendidikan formal responden Subak Tajen masih tergolong tinggi, hal ini dapat dilihat dari pendidikan yang dikenyam 10 orang $(41,67 \%)$ responden adalah SMA sedangkan hanya satu orang $(4,16 \%)$ responden yang tidak mengenyam pendidikan. Responden dengan tingkat pendidikan tamat SD sebanyak sembilan orang $(37,50 \%)$ dan respoden dengan tingkat pendidikan tamat SMP sebanyak empat orang $(16,67 \%)$.

\subsubsection{Jenis pekerjaan}

Mata pencaharian pokok terbanyak responden sebagai petani yaitu 19 orang $(79,16 \%)$, tiga orang $(12,50)$ sebagai pegawai swasta, satu orang $(4,17)$ sebagai PNS dan satu orang $(4,17)$ sebagai pedagang. Pekerjaan sampingan terbanyak yang dimiliki oleh responden adalah pekerja bangunan sebanyak tujuh orang $(29,17 \%)$, lima orang $(20,83)$ sebagai petani, dan sisanya tidak memiliki pekerjaan sampingan.

\subsubsection{Jumlah anggota rumah tangga}

Berdasarkan hasil penelitian, rata-rata anggota rumah tangga responden adalah 3,25 orang yang terdapat pada kisaran jumlah satu sampai dengan tujuh orang. Sebanyak 12 rumah tangga $(50,00 \%)$ tergolong kelompok dengan jumlah anggota rumah tangga antara tiga sampai empat orang, sembilan rumah tangga $(37,50 \%)$ tergolong kelompok dengan jumlah anggota rumah tangga antara satu sampai dua orang, dua rumah tangga $(8,33 \%)$ tergolong kelompok dengan jumlah anggota rumah tangga antara lima sampai enam orang dan satu rumah tangga $(4,17 \%)$ dengan jumlah anggota rumah tangga tujuh orang. Secara keseluruhan jumlah tanggungan responden sebanyak 78 orang.

\subsubsection{Pemilikan dan penggunaan lahan}

Rata-rata luas lahan sawah yang dimiliki responden seluas 22,08 are. Rata-rata luas lahan garapan responden seluas 43,96 are yang terdiri dari lahan milik seluas 21,83 are dan lahan nyakap seluas 22,13 are. Responden juga menyewakan lahannya ke petani lain yaitu seluas 0,25 are. Rata-rata luas pekarangan yang dimiliki responden adalah 5,67 are yang digunakan sebagai pemukiman atau tempat tinggal dan pada lahan tegalan rata-rata luas lahan yang dimiliki seluas 23,75 are yang dikerjakan sendiri tanpa disakapkan atau disewakan ke petani lain. Umumnya tanah tegalan ditanami jenis tanaman seperti kakao, kelapa, kopi, pisang dan lain-lain.

\subsection{Perilaku Petani terhadap Program Gerbang Pangan Serasi}

Penelitian ini mengkaji tentang aspek perilaku petani terhadap Program Gerbang Pangan Serasi yang dilihat dari pengetahuan, sikap, dan keterampilan. Program Gerbang Pangan Serasi ini terdiri atas tiga sub program yaitu budidaya padi 
organik, bantuan ternak sapi, serta pelatihan dan pendidikan pembuatan pupuk organik dan pestisida nabati. Berdasarkan hasil penelitian ditemukan bahwa perilaku petani terhadap Program Gerbang Pangan Serasi di Subak Tajen yang mendapat bantuan ternak sapi termasuk dalam kategori baik dengan pencapaian skor 3,94, sedangkan perilaku petani terhadap Program Gerbang Pangan Serasi yang tidak mendapat bantuan ternak sapi termasuk dalam kategori sedang dengan pencapaian skor 3,35. Rata-rata pencapaian skor pengetahuan, sikap, dan keterampilan petani terhadap Program Gerbang Pangan Serasi disajikan pada Tabel 1.

Tabel 1.

Perilaku Petani Terhadap Program Gerbang Pangan Serasi di Subak Tajen Desa Tajen, Kecamatan Penebel, Kabupaten Tabanan, Tahun 2016

\begin{tabular}{lcccc}
\hline \multirow{2}{*}{ Konsep } & \multicolumn{2}{c}{ Pencapaian skor } & \multicolumn{2}{c}{ Kategori } \\
\cline { 2 - 5 } & $\begin{array}{c}\text { Mendapat } \\
\text { bantuan } \\
\text { sapi }\end{array}$ & $\begin{array}{c}\text { Tidak } \\
\text { mendapat } \\
\text { bantuan sapi }\end{array}$ & $\begin{array}{c}\text { Mendapat } \\
\text { bantuan sapi }\end{array}$ & $\begin{array}{c}\text { Tidak mendapat } \\
\text { bantuan sapi }\end{array}$ \\
\hline Pengetahuan & 3,91 & 3,01 & Tinggi & Sedang \\
Sikap & 4,08 & 3,69 & Setuju & Setuju \\
Keterampilan & 3,82 & 2,78 & Baik & Sedang \\
\hline Perilaku & 3,94 & 3,35 & Baik & Sedang \\
\hline
\end{tabular}

\subsection{Pengetahuan Petani Tentang Program Gerbang Pangan Serasi}

Hasil penelitian menunjukkan pengetahuan petani yang mendapat bantuan sapi dalam Program Gerbang Pangan Serasi tergolong kategori tinggi dengan pencapaian skor 3,91.Tingkat pengetahuan tertinggi petani yang mendapat bantuan sapi adalah pada pengetahuan tentang bantuan ternak sapi dengan pencapaian skor 4,75 termasuk kategori sangat tinggi. Sebagian besar petani sudah mengetahui tentang bantuan ternak sapi yang didapatkan dalam program yang mencakup proses pengadaan ternak sapi serta bantuan biaya pengadaan/rehab kandang dan mekanisme penggunaan biaya. Pencapaian skor pengetahuan petani yang mendapat bantuan sapi tentang budidaya padi organik juga termasuk dalam kategori tinggi dengan pencapaian skor 4,12 .

Pengetahuan petani yang tidak mendapat bantuan sapi tergolong kategori sedang dengan pencapaian skor 3,01. Pencapaian skor pengetahuan tertinggi petani yang tidak mendapat bantuan sapi terdapat pada pengetahuan tentang budidaya padi organik dengan pencapaian skor 4,13 termasuk dalam kategori tinggi. Kategori tinggi ini menunjukkan bahwa sebagian besar petani, baik yang mendapat atau tidak mendapat bantuan sapi sudah mengetahui tahap-tahap budidaya padi secara organik mulai dari tahap pengadaan benih sampai dengan tahap panen.

Pencapaian skor pengetahuan terendah petani terdapat pada pelatihan dan pendidikan dengan pencapaian skor 2,88 untuk petani yang mendapat bantuan sapi termasuk kategori sedang dan 1,88 untuk petani yang tidak mendapat bantuan sapi 
termasuk kategori rendah. Petani yang mendapat bantuan sapi mendapat kategori sedang karena dari empat jenis pelatihan dan pendidikan yang diterima, sebagian besar petani hanya mengetahui dua jenis pelatihan saja yaitu pelatihan pembuatan pupuk organik dan pelatihan pembuatan bio urine, sedangkan untuk petani yang tidak mendapat bantuan sapi, kategori rendah ini diperoleh karena sebagian besar petani hanya mengetahui tentang pelatihan pembuatan pupuk organik, namun pada tiga jenis pelatihan lainnya pengetahuan petani termasuk dalam kategori sangat rendah.

Proses budidaya padi organik dalam Program Gerbang Pangan Serasi memiliki tiga keunggulan atau perbedaan dengan budidaya padi pada umumnya yaitu pada tahap pemupukan organik, pengendalian hama penyakit terpadu, dan pemasaran. Hasil penelitian menunjukkan sebagian besar petani sudah mengetahui tahap pemupukan organik yang tidak memperbolehkan petani untuk menggunakan pupuk kimia, pengendalian hama penyakit terpadu menggunakan pestisida nabati dan bio urine dan pemasaran hasil yang dipasarkan kepada lembaga yang sudah diajak bekerjasama dalam Program Gerbang Pangan Serasi tersebut.

\subsection{Sikap Petani Terhadap Program Gerbang Pangan Serasi}

Sikap petani yang mendapat bantuan sapi terhadap Program Gerbang Pangan Serasi tergolong dalam kategori setuju dengan pencapaian skor 4,08. Pencapaian skor sikap tertinggi petani yang mendapat bantuan sapi terdapat pada sikap terhadapbantuan ternak sapi dengan pencapaian skor 4,50 termasuk kategori sangat setuju. Kategori setuju ini dikarenakan sebagian besar petani sudah sangat setuju terhadap bantuan ternak sapi yang didapatkan dalam program mulai dari proses pengadaan ternak sapi serta bantuan biaya pengadaan/rehab kandang dan mekanisme penggunaan biaya. Pencapaian skor sikap petani yang mendapat bantuan sapi terhadap budidaya padi organik termasuk dalam kategori setuju dengan pencapaian skor 4,14, sedangkan pencapaian skor sikap tertinggi petani yang tidak mendapat bantuan sapi adalah pada sikap terhadap budidaya padi organik dengan pencapaian skor 4,14 termasuk dalam kategori setuju. Kategori setuju ini menunjukkan bahwa sebagian besar petani sudah menyetujui tahap-tahap budidaya padi secara organik sesuai aturan program.

Pencapaian skor sikap terendah petani yang mendapat bantuan sapi terdapat pada pelatihan dan pendidikan dengan pencapaian skor 3,61 termasuk kategori setuju. Kategori setuju disebabkan oleh sikap petani yang sudah setuju terhadap pelatihan pembuatan pupuk organik dengan pencapaian skor 4,00 dan pelatihan pembuatan bio urine dengan pencapaian skor 4,04, namun sikap petani masih raguragu terhadap pelatihan pembuatan pestisida nabati CAGASI serta pelatihan pembuatan pestisida nabati ekstrak jahe, lengkuas, kunyit, dan labu siam.

Sikap petani yang tidak mendapat bantuan sapi tergolong dalam kategori setuju dengan pencapaian skor 3,69. Pencapaian skor sikap tertinggi petani yang tidak mendapat bantuan sapi adalah pada sikap terhadap budidaya padi organik dengan 
pencapaian skor 4,08 termasuk dalam kategori setuju. Kategori setuju ini menunjukkan bahwa sebagian besar petani sudah menyetujui tahap-tahap budidaya padi secara organik sesuai aturan program.

Pencapaian skor sikap terendah petani yang tidak mendapat bantuan sapi juga terdapat pada pelatihan dan pendidikan dengan pencapaian skor 3,29 termasuk kategori ragu-ragu. Kategori ragu-ragu dikarenakan sebagian besar petani masih memiliki sikap yang ragu-ragu terhadap tiga jenis pelatihan dari empat jenis pelatihan dan pendidikan yang diberikan yaitu pelatihan pembuatan bio urine, pelatihan pembuatan pestisida nabati CAGASI serta pelatihan pembuatan pestisida nabati ekstrak jahe, lengkuas, kunyit dan labu siam. Hasil wawancara menunjukkan sikap ragu-ragu petani terhadap pelatihan dan pendidikan khususnya pelatihan pembuatan pestisida nabati dikarenakan petani mengaku sudah lupa tentang beberapa bahan dan cara untuk membuat pestisida nabati tersebut, sehingga petani ragu-ragu dalam menentukan sikap terhadap pernyataan yang diberikan.

Sikap petani terhadap tahap pemupukan organik, pengendalian hama penyakit terpadu dan pemasaran sudah setuju. Hasil penelitian menunjukkan sebagian besar petani sudah setuju dengan tahap pemupukan organik yang tidak memperbolehkan petani untuk menggunakan pupuk kimia, pengendalian hama penyakit terpadu menggunakan pestisida nabati dan bio urine dan petani juga sudah setuju untuk memasarkan hasil panen mereka kepada lembaga yang sudah diajak bekerjasama dalam Program Gerbang Pangan Serasi tersebut, namun petani berharap agar hasil panennya dibayar secara langsung.

\subsection{Keterampilan Petani tentang Program Gerbang Pangan Serasi}

Keterampilan petani yang mendapat bantuan sapi dalam Program Gerbang Pangan Serasi tergolong dalam kategori baik dengan pencapaian skor 3,82. Pencapaian skor keterampilan tertinggi petani yang mendapat bantuan sapi adalah pada ketrampilan tentang bantuan ternak sapi dengan pencapaian skor 4,75 termasuk kategori sangat tinggi. Kategori sangat tinggi ini dikarenakan sebagian besar petani sudah menerapkan bantuan ternak sapi yang didapatkan dalam program sesuai kriteria, mekanisme pengadaan ternak sapi sesuai dengan ketentuan dalam program dan penggunaan bantuan biaya pengadaan/rehab kandang dan mekanisme penggunaan biaya sesuai aturan yang ada. Petani sudah membeli sapi sesuai dengan kriteria yang sudah di atur dalam program serta mengikuti mekanisme pengadaan ternak sapi yang sudah ditentukan. Pencapaian skor keterampilan petani yang mendapat bantuan sapi terhadap budidaya padi organik termasuk dalam kategori baik dengan pencapaian skor 4,10 karena sebagian besar petani sudah bisa mengikuti tahap-tahap dalam budidaya padi organik sesuai dengan ketentuan program.

Pencapaian skor keterampilan terendah petani yang mendapat bantuan sapi terdapat pada pelatihan dan pendidikan dengan pencapaian skor 2,61 termasuk kategori sedang. Kategori sedang ini didapat karena dari empat jenis pelatihan dan pendidikan pembuatan pupuk organik dan pestisida nabati yang diterima, sebagian 
besar petani hanya membuat dan menerapkan pupuk organik serta bio urine dalam budidaya padi organiknya. Hasil wawancara menunjukkan sebagian besar petani tidak membuat dan menerapkan pestisida nabati CAGASI serta pestisida nabati ekstrak jahe, lengkuas, kunyit, dan labu siam dalam kegiatan budidaya padi organiknya karena petani lebih memilih menggunakan bio urine atau menggunakan pestisida jenis lain.

Keterampilan petani yang tidak mendapat bantuan sapi tergolong dalam kategori sedang dengan pencapaian skor 2,78. Pencapaian skor keterampilan tertinggi petani yang tidak mendapat bantuan sapi terdapat pada keterampilan dalam budidaya padi organik dengan pencapaian skor 4,12 termasuk dalam kategori baik. Hal ini menunjukkan bahwa sebagian besar petani tidak mendapat bantuan sapi sudah mengikuti atau menerapkan tahap-tahap budidaya padi secara organik sesuai aturan dalam program.

Pencapaian skor keterampilan terendah petani yang tidak mendapat bantuan sapi terdapat pada pelatihan dan pendidikan dengan pencapaian skor 1,45 termasuk kategori sangat tidak baik. Kategori sangat tidak baik tersebut menunjukkan bahwa sebagian besar petani tidak membuat pupuk organik, bio urine, pestisida nabati CAGASI serta pestisida nabati ekstrak jahe, lengkuas, kunyit, dan labu siam dalam kegiatan budidaya padi organiknya. Hasil wawancara menunjukkan petani tidak membuat pupuk organik dan bio urine dengan alasan tidak memiliki bahan, sedangkan tidak menggunakan pestisida nabati CAGASI serta pestisida nabati ekstrak jahe, lengkuas, kunyit, dan labu siam karena lebih memilih menggunakan pestisida nabati jenis lain dan bio urine dalam pengendalian hama penyakit.

Keterampilan petani pada tahap pemupukan organik, pengendalian hama penyakit terpadu dan pemasaran dapat diketahui bahwa petani sudah mengikuti tahapan tersebut sesuai ketentuan yang ada. Hasil wawancara menunjukkan sebagian besar petani sudah menggunakan pupuk organik dan tidak menggunakan pupuk kimia dalam budidaya padi organiknya. Petani sudah menggunakan pestisida nabati dan bio urine untuk mengendalikan hama dan penyakit yang mengganggu tanaman padinya dansudah memasarkan hasil panennya kepada lembaga yang diajak bekerjasama dalam Program Gerbang Pangan Serasi tersebut.

\section{Simpulan dan Saran}

\subsection{Simpulan}

Berdasarkan hasil penelitian tentang perilaku petani terhadap Program Gerbang Pangan Serasi dapat disimpulkan bahwa perilaku petani yang mendapat bantuan sapi tergolong baik dengan pencapaian skor 3,94, sedangkan perilaku petani yang tidak mendapat bantuan sapi tergolong kategori sedang dengan pencapaian skor 3,16. Perilaku tersebut terbentuk dari pengetahuan, sikap, dan keterampilan sebagai berikut. 
1. Pengetahuan petani yang mendapat bantuan sapi termasuk kategori tinggi dengan pencapaian skor 3,91, sedangkan pengetahuan petani yang tidak mendapat bantuan sapi termasuk kategori sedang dengan pencapaian skor 3,01 .

2. Sikap petani yang mendapat bantuan sapi termasuk kategori setujudengan pencapaian skor 4,08, sedangkan sikap petani yang tidak mendapat bantuan sapi termasuk kategori setuju dengan pencapaian skor 3,69.

3. Keterampilan petani yang mendapat bantuan sapi termasuk kategori baik, dengan pencapaian skor 3,82, sedangkan keterampilan petani yang tidak mendapat bantuan sapi termasuk kategori sedang dengan pencapaian skor 2,78.

\subsection{Saran}

Berdasarkan temuan-temuan penelitian dapat disarankan sebagai berikut.

1. Program Gerbang Pangan Serasi mempunyai tiga sub program yaitu budidaya padi organik, bantuan ternak sapi dan pelatihan pembuatan pupuk organik, bio urine serta pembuatan pestisida nabati, namun dari 34 orang petani penerima Program Gerbang Pangan Serasi hanya 12 orang yang mendapat bantuan ternak sapi. Melihat hal tersebut, pemerintah perlu memberikan bantuan sapi kepada seluruh petani yang menerapkan program, sehingga semua petani penerima program dapat menjalankan program lebih maksimal terutama pada sub program pelatihan pembuatan pupuk organik, bio urine, dan pembuatan pestisida nabati yang masih kurang dalam penerapannya terutama untuk petani yang tidak mendapatkan bantuan sapi karena masih ada petani yang beralasan tidak mempunyai bahan untuk membuat pupuk organik, bio urine, dan pestisida nabati.

2. Pada aspek pemasaran, pemerintah perlu menjamin hasil panen petani dibayar secara langsung dan dengan harga yang lebih tinggi oleh pihak pembeli yaitu lembaga atau rekanan yang diajak bekerja sama untuk membeli hasil panen petani dalam Program Gerbang Pangan Serasi tersebut, sehingga petani tidak dirugikan karena pembayaran hasil panenya tertunda.

3. Upaya yang dapat dilakukan untuk mengatasi masalah ketersediaan bahan pembuatan pupuk organik dan bio urine dan pestisida nabati bagi petani yang tidak mendapat bantuan sapi, dapat dibentuk kelompok pembuatan pupuk organik dan pestisida nabati bagi petani penerima Program Gerbang Pangan Serasi, sehingga semua petani penerima program, baik yang mendapat atau tidak mendapat bantuan sapi bisa terlibat dalam pembuatan pupuk organik dan pestisida nabati untuk memenuhi kebutuhan pupuk organik dan pestisida nabati dalam budidaya padi organik. Petani juga perlu mencoba teknologi baru atau inovasi dalam bidang pertanian seperti pelatihan dan pendidikan pembuatan pupuk organik, bio urine dan pestisida nabati yang diterima, seharusnya petani mau menerapkan atau mencoba membuat pupuk organik, bio urine dan pestisida nabati seperti yang sudah diajarkan dalam budidaya padi organiknya khususnya 
bagi petani yang tidak mendapat bantuan sapi agar bisa mengurangi biaya untuk pembelian pupuk.

\section{Ucapan Terima Kasih}

Penulis menyampaikan terima kasih kepada anggota subak yang telah memberikan data penelitian dan semua pihak yang telah membantu dan memberikan dukungan baik secara moral maupun material dalam proses penyelesaian penulisan ini sampai termuat di e-jurnal.

\section{Daftar Pustaka}

Adi, Istiqomah Buddhisatyani. 2013. Kajian Preparasi dan Kondisi Optimum Ekstraksi ionutrien Berbasis Tanaman SO-23.http://repository.upi.edu /2908/4/SKIM 0607350Chapter1.pdf.Di akses pada 20 Juni 2016.

Anonim, 2014. Profil Desa Tajen. Kecamatan Penebel. Tabanan

Badan Pelaksana Penyuluhan Pertanian, Perikanan, dan Kehutanan Kabupaten Tabanan. 2015. Petunjuk Teknis/Kerangka Acuan Percontohan Sistem Pertanian Organik Padi dan Sayur (Gerbang Pangan Serasi Lanjutan).Tabanan : BP3K Kabupaten Tabanan.

Gulo, W. 2002. Metode Penelitian. Gramedia Widiasarana Indonesia.Jakarta.

Gustian Nugraha N. 2013. Kajian Potensi Bionutrien PBAG terhadap Pertumbuhan Padi.http://repository.upi.edu/9182/2/s_kim_0786369_chapter1.pdf. Di akses pada 10 Agustus 2016.

Mosher, A.T.,1991. Menggerakkan dan Membangun Pertanian.CV. N Yayaguna. Jakarta.

Rowland B. F. Pasaribu. 2013. Populasi dan sampel.https://rowland pasaribu.files.wordpress.com/2013/03/06-populasi-dan-sampel1.pdf. Diakses pada 1 April 2016.

Singarimbun, M dan S. Effendi. 1989. Metode Penelitian Survei. LP3ES, Jakarta

Sudarta, W. 2005. Pengetahuan dan Sikap Petani Terhadap Pengendalian Hama TanamanTerpadu(Online).http://ejournal.unud.ac.id/abstrak/(6)\%20socasudarta-pks\%20pht(2).pdf. Diakses pada 23 Februari 2016.

Thoha. 2004. Faktor yang Mempengaruhi Perkembangan Persepsi Seseorang. $\{$ Jurnal Online\}.http://id.shvoong.com. Diunduh Tanggal 20 Desember 2016. 